\title{
STUDI POTENSI LOKASI RAWAN KECELAKAAN BUSWAY TRANSJAKARTA DI KORIDOR 10
}

\author{
Budi Hartanto Susilo ${ }^{1}$, Firman ${ }^{2}$ \\ ${ }^{1}$ Dosen Jurusan Teknik Sipil, Fakultas Teknik, Universitas Kristen Maranatha \\ ${ }^{2}$ Mahasiswa Magister Teknik Sipil, Fakultas Teknik Sipil dan Lingkungan, Institut Teknologi \\ Bandung
}

\begin{abstract}
ABSTRAK
Sejak 15 Januari 2004 Pemerintah Propinsi DKI Jakarta resmi mulai mengoperasikan sistem angkutan masal baru "TransJakarta" di kota metropolitan Jakarta dengan Koridor-1 yang telah selesai dibangun pada Tahap-I. Keseluruhan rencana meliputi 15 koridor Busway yang dibangun secara bertahap. Khusus pada koridor 10 kondisinya bertambah rumit karena banyaknya akses pintu masuk dan keluar tol. Hasil inspeksi keselamatan jalan ditemukan ada beberapa kendala yang dapat menyebabkan kecelakaan lalulintas di sepanjang koridor 10. Beberapa hal yang perlu diperhatikan mengenai kecelakaan lalulintas jalan di koridor 10 adalah akses pintu tol Tanjung Priok. Banyaknya kendaraan berat yang melewati lokasi tersebut dapat mengakibatkan rawan konflik pada jalur Busway. Ada beberapa rekomendasi yang diusulkan berdasarkan hasil investigasi Lokasi Rawan Kecelakaan dan pencegahannya yang dilakukan pada lokasi-lokasi yang dianggap paling mengkhawatirkan dari segi keamanan dan kenyamanan bagi lajur Busway seperti pembuatan lajur khusus Busway pada area simpang secara bertahap untuk menghindari konflik dengan kendaraan lainnya di simpang Enggano. Makalah ini bermaksud untuk mengurangi dampak dari pengoperasian Busway di Koridor 10 ditinjau dari segi aspek keselamatan jalan.
\end{abstract}

Kata kunci: potensi lokasi rawan kecelakaan, busway TransJakarta, koridor 10.

\begin{abstract}
Since January 15, 2004 Government of DKI Jakarta Province officially started operating a new mass transit system "Trans Jakarta" in the metropolitan city of Jakarta in Corridor-1 which was completed in Phase-I. The overall plan covers 15 busway corridors are constructed in stages. Special on 10 corridors has complicated condition because of the large increase access entrance and exit toll. The result of road safety inspection found that there are several obstacles that can cause traffic accidents along the corridor busway 10. Some things to note about road traffic accidents in the corridor 10 is the access door Tanjung Priok toll. Number of heavy vehicles passing through these locations can lead to potential conflict in the Busway route. There are several proposed recommendations based on the results of the investigation and prevention Potential Accident Locations conducted in locations that are considered the most worrying in terms of safety and comfort for lane Busway like making a special lane for Busway at the intersection area in stages to avoid conflicts with other vehicles at intersections Enggano. This paper intends to reduce the impact of the operation of the Busway Corridor 10 in terms of road safety aspect
\end{abstract}

Keywords: Potential Accident Locations, Busway TransJakarta, Corridor 10.

\section{PENDAHULUAN}

\subsection{Latar Belakang}

Alat transportasi bus di kebanyakan belahan dunia saat ini tidaklah mendorong besarnya keinginan baik pelanggan. Pelayanan bus seringkali kurang dapat diandalkan, kurang nyaman, dan berbahaya. Sebaliknya, para pembuat rencana transportasi dan pejabat publik terkadang malah berbalik pada alternatif angkutan umum seperti kereta 
Metro. Namun ada suatu alternatif antara layanan untuk orang kurang berada dan beban kota yang tinggi. Bus Rapid Transit (Angkutan Bus Cepat / BRT) bisa memberikan layanan angkutan berkualitas tinggi seperti Metro dengan besar biaya hanya sebagian dari biaya pilihan-pilihan lainnya (Wright, 2002).

Sejak 15 Januari 2004 Pemerintah Propinsi DKI Jakarta resmi mulai mengoperasikan sistem angkutan masal baru "Trans Jakarta Busway" di kota metropolitan Jakarta dengan Koridor-1 yang telah selesai dibangun pada Tahap-I. Keseluruhan rencana meliputi 15 koridor Busway yang dibangun secara bertahap. Pada Tahap-II dibangun dan dioperasikan Koridor 2 dan Koridor 3.

Berbeda dengan Koridor pertama yang relatif lebih kondusif dan longgar, maka kondisi pembangunan koridor-koridor yang belakangan menjumpai banyak keterbatasan dan hambatan. Jalur bus atau busway seringkali berebut ruang lalulintas yang sangat terbatas sehingga harus berbagi dengan lalulintas umum atau 'mix traffic'. Khusus pada Koridor 9 dan 10 kondisinya bertambah rumit karena berbatasan langsung dengan jalan bebas hambatan (jalan tol) sehingga dapat terjadi konflik pada ramps-ramps atau pintu masuk/keluar jalan tol (Dishub DKI Jakarta, 2004).

\subsection{Maksud dan Tujuan}

Maksud pekerjaan ini merekomendasikan perbaikan-perbaikan yang dapat dilakukan untuk meningkatkan keselamatan lalulintas pengguna jalan di Koridor 10 . Sedangkan tujuan dari penelitian ini adalah meningkatkan keselamatan lalulintas pengguna jalan pada Koridor 10 .

\subsection{Ruang Lingkup Studi}

Ruang lingkup studi yang untuk melakukan evaluasi mengenai keselamatan lalulintas di Koridor 10 meliputi:

1) Mendata, memetakan dan menganalisa lokasi rawan kecelakaan lalulintas (lakalantas) di sepanjang Koridor 10 serta solusi yang harus dilakukan terkait pengoperasian Busway Transjakarta.

2) Menilai dan mengaudit kondisi geometrik jalur Busway yang sudah terbangun berdasarkan keselamatan bagi pengguna jalan dan lingkungan sepanjang Koridor 10.

3) Memprediksi potensi kecelakaan yang mungkin terjadi berdasarkan survei fisik dan geometrik jalan. 


\section{PENGGUNAAN BRT DI NEGARA MAJU}

\subsection{Gambaran Umum}

Dengan kecenderungan saat ini, masa depan transportasi umum semakin diragukan. Kendaraan pribadi memenangkan pertarungan pembagian moda. Bila pendapatan bertambah di negara-negara berkembang kendaraan pribadi semakin banyak digunakan, sedangkan rit transportasi umum menurun hampir secara keseluruhan. BRT adalah jawaban transportasi umum bagi penyusutan ini, dengan upaya untuk menyediakan layanan yang kompetitif dengan mobil pribadi (PemProv DKI Jakarta, 2003).

Alasan hilangnya transportasi umum tidaklah sulit untuk dipahami (seperti yang terlihat pada Gambar 1). Layanan angkutan yang buruk baik di negara maju maupun berkembang mendorong konsumen pada pilihan kendaraan pribadi. Daya tarik mobil pribadi dan motor adalah dalam hal performansi dan citranya. Pengguna transportasi umum biasanya mengemukakan alasan-alasan berikut mengenai pengalihannya ke kendaraan pribadi:

1) Ketidaknyamanan dalam hal lokasi stasiun dan frekuensi layanan.

2) Takut akan kejahatan di stasiun dan di dalam bus.

3) Kurangnya keamanan dalam hal kemampuan pengemudi dan kelaikan jalan bus-bus.

4) Layanan jauh lebih lambat dibandingkan dengan kendaraan pribadi, khususnya saat bus sering berhenti.

5) Padatnya kendaraan membuat perjalanan menjadi tidak nyaman.

6) Transportasi publik bisa menjadi relatif mahal untuk sebagian rumah tangga di negara-negara berkembang.

7) Kurangnya struktur sistem yang terorganisasi serta kurangnya peta-peta dan informasi yang menyertainya membuat sistem tersebut menjadi sulit untuk digunakan; dan

8) Status layanan angkutan umum yang rendah. 


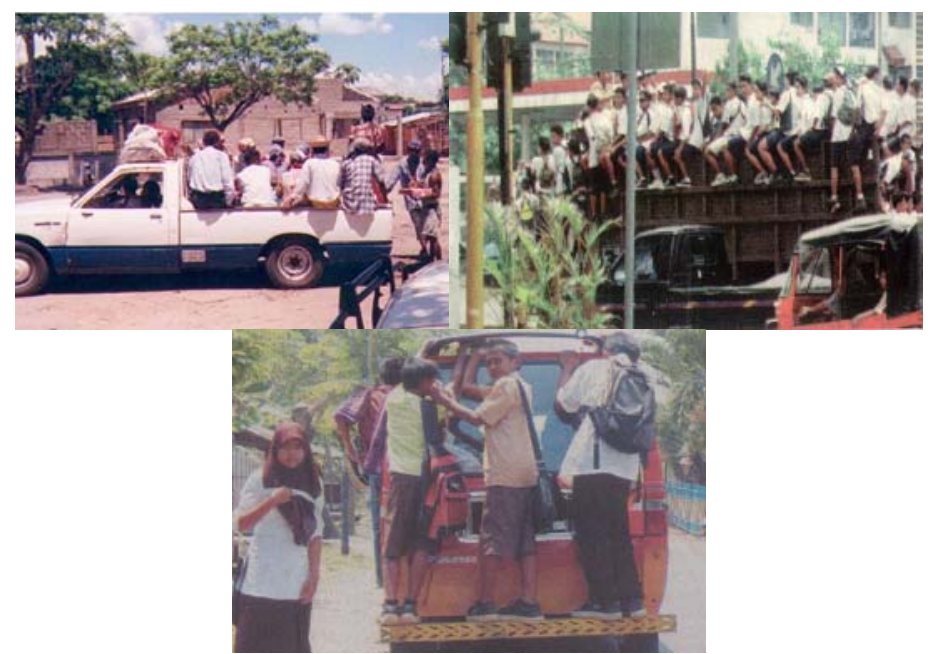

Gambar 1 Kondisi pelayanan angkutan umum yang buruk dan membahayakan.

\subsection{Perencanaan dan Desain yang Aman dan Nyaman}

Para perancang sistem terkadang salah mengasumsikan bahwa jalan-jalan arteri utama saja yang merupakan opsi bagi busway eksklusif. Kenyataannya, ada banyak opsi koridor yang dapat dipertimbangkan. Jalan-jalan arteri utama biasanya memang menyediakan skala ekonomi dalam hal aliran pelanggan karena daerah asal dan tujuan utama sering kali ditempatkan pada jalan raya utama (principal thouroughfare). Namun, mungkin akan ada waktu-waktu saat aliran lalulintas yang ada ternyata tidak memungkinkan pengubahan jalur ke busway. Lebih jauh, arteri seperti itu mungkin tidak memberikan akses yang mudah dan aman bagi para pejalan kaki untuk mencapai sistem BRT. Oleh karena itu, alternatif lain termasuk jalan-jalan sekunder tersebut biasanya unggul dalam hal bahwa jalan tersebut lebih “tenang” bagi pengubahan busway yang efektif. Pada beberapa kasus, sebuah jalan sekunder mungkin secara keseluruhan diubah untuk penggunaan BRT, dan oleh karena itu mencegah akses kendaraan pribadi. Kemungkinan pendekatan ini bisa terjadi tergantung pada pola penggunaan yang sudah ada di daerah tersebut.

Lokasi busway yang terpisah merupakan keputusan desain lain yang mungkin lebih memberikan banyak opsi daripada yang mungkin segera tampak. Opsi yang paling umum adalah menempatkan busway di median tengah atau di tengah dua jalur. Konfigurasi ini mengurangi pertemuan dengan bagian sebelah kanan (di negara-negara yang menjalankan kendaraannya pada sisi jalan sebelah kanan). Konfigurasi ini juga memungkinkan opsi-opsi yang lebih terintegrasi dengan busway line yang mungkin melintas pada jalan yang tegak lurus. Terlepas dari konfigurasi jalur tengah, ada berbagai 
alternatif yang seringkali tidak terlalu mendapat pertimbangan penuh. Di Miami, kedua jalur busway secara menyeluruh beroperasi pada satu sisi jalan besar, sedangkan lalulintas campuran mendapatkan beberapa jalur (kedua arah) di sisi lainnya (Fjellstrom, 2002).

\section{GAMBARAN KECELAKAAN LALULINTAS JALAN}

Kecelakaan kadang-kadang disebut sebagai 'Act of God' atau takdir, padahal kecelakaan bukanlah peristiwa yang tidak dapat dikendalikan seperti bencana alam (ITE, 1982). Melalui analisis mikro yang bersifat individual oleh ahli yang berpengalaman dengan pertimbangan yang baik dan usaha kerasnya, maka sebab-akibat dan proses terjadinya kecelakaan tersebut dapat diuraikan dengan jelas dan sistematis termasuk penyebab tunggal maupun penyebab yang jamak berantai hingga terjadinya suatu kecelakaan (Kadiyali, 1983; Odgen, 1984; Yu, 1982).

Secara umum kecelakaan transportasi disebabkan oleh salah satu atau kombinasinya dari 3 elemen sistem transportasi yaitu: pengguna jalan, kendaraan dan jalannya itu sendiri termasuk lingkungannya. Dengan memperbaiki elemen-elemen ini diharapkan dapat meningkatkan keselamatan transportasi atau mengurangi potensi kecelakaan lalulintas (ITE, 1992).

Faktor-faktor utama penyebab kecelakaan adalah pengguna jalan, lingkungan jalan dan kendaraan dengan nilai kontribusinya masing-masing maupun kombinasinya seperti terlihat pada Gambar 2 (O’Flaherty, 1997).

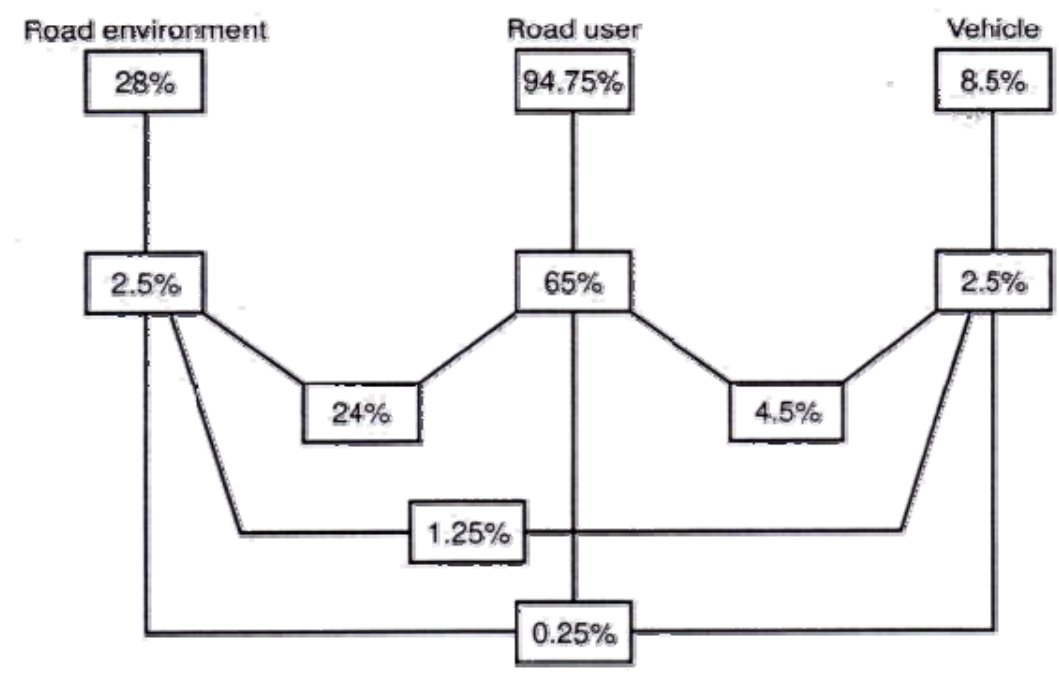

Gambar 2 Kontribusi pada Kecelakaan Jalan. 


\section{POTENSI LOKASI RAWAN KECELAKAAN JALAN}

\subsection{Analisa Lokasi Rawan Kecelakaan}

Melalui pengamatan dari data GPS dan penentuan titik-titik ikat menggunakan odometer maka didapat beberapa titik lokasi rawan kecelakaan dan tundaan. Dalam hal ini, ada beberapa faktor yang menjadi penyebab kecelakaan lalulintas di jalan, seperti Laju urbanisasi (urbanization rate) yang tinggi; Pertumbuhan jumlah kendaraan yang tinggi; Jaringan jalan tidak didesain sesuai dengan jenis dan volume lalulintas saat ini; Pertumbuhan daerah urban yang tidak terencana dengan baik sehingga menyebabkan guna lahan tidak compatible; Perpindahan penduduk dari daerah rural ke pusat kota, yang menyebabkan "new urban resident" tidak dapat menyesuaikan diri dengan kondisi lalulintas kota (gaya kota, pola pikir desa); Pemeliharaan jalan yang tidak memadai; Persimpangan yang tidak didesain dengan baik; Fasilitas bagi pejalan kaki yang tidak memadai.

Untuk keselamatan lalulintas jalan di Koridor Busway 10 lebih ditekankan kepada desain jalan dan manajemen lalulintas di sepanjang koridor tersebut. Ditinjau dari segi aspek perancangan ada beberapa hal yang harus diperhatikan, yaitu mengenai implementasi desain jalan yang substandar sudah seringkali merenggut korban jiwa. Hasil inspeksi keselamatan jalan ditemukan ada beberapa kendala yang dapat menyebabkan kecelakaan lalulintas di sepanjang koridor busway 10, antara lain separator atau pemisah antara lajur Busway dan kendaraan lainnya; Simpang bersinyal, besarnya waktu antrian pada lokasi simpang bersinyal dapat mengakibatkan tabrak belakang pada antrian; Kondisi drainase dan trotoar yang kurang memadai ditinjau dari segi aspek keselamatan antara lain penutup saluran jalan dan kondisi paving trotoar.

\subsection{Analisa Lokasi Persimpangan}

Analisis lokasi persimpangan sangat diperlukan untuk mengatasi rawan tundaan. Hal ini dikarenakan di daerah lokasi persimpangan sepanjang Koridor 10 sangat berpotensi rawan kemacetan. Lokasi persimpangan yang menjadi perhatian di Koridor 10 yaitu simpang Enggano.

Pada lokasi ini, jalur busway terlalu banyak memotong jalur/lajur lainnya (2 lajur) sehingga menimbulkan konflik yang cukup besar. Oleh karena itu, jalur busway pada simpang ini dapat dibuat sedemikian rupa sehingga tidak langsung memotong 2 lajur sekaligus tetapi dibuat secara bertahap seperti pada Gambar 3. Alternatif lain yang dapat dilakukan adalah menerapkan fase sinyal khusus untuk Busway. 


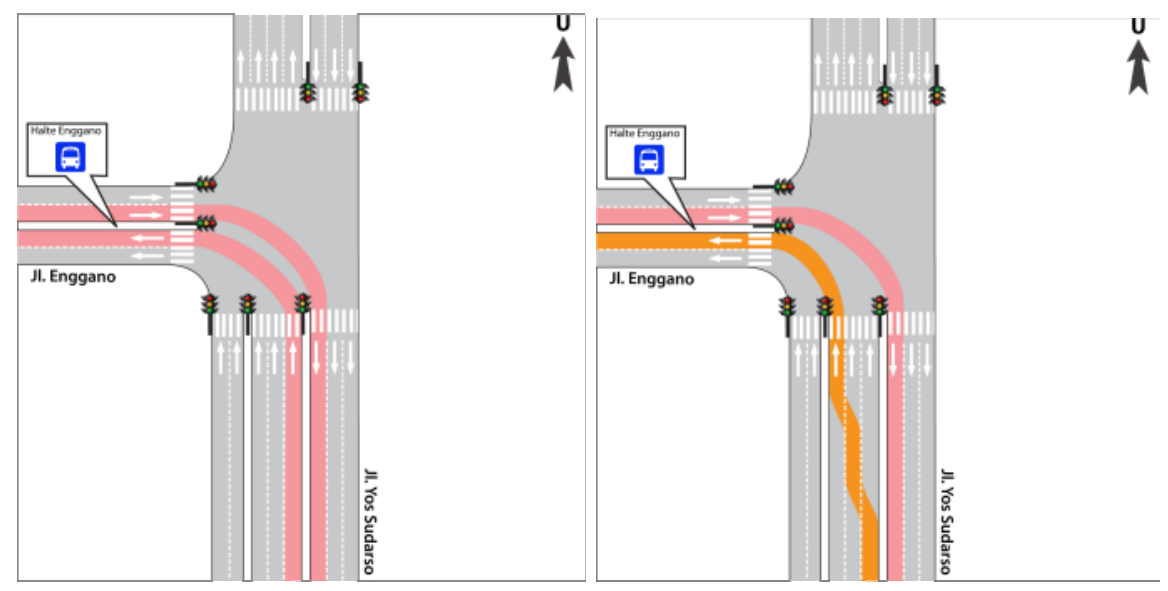

Gambar 3 (a) Sketsa eksisting simpang Enggano dan (b) Sketsa usulannya.

\subsection{Pintu Masuk dan Keluar Tol}

Kasus yang menjadi perhatian mengenai lokasi pintu masuk dan keluar Tol pada koridor 10 yaitu di dekat pintu tol Tanjung Priok, seperti yang terlihat pada Gambar 4. Untuk kasus ini perlu ditambahkan beberapa rambu dan marka sebagai berikut pada lajur lalulintas umum (termasuk jalur busway) dan arah keluar Tol:

1) Rambu peringatan "Hati-Hati, Jalur Busway" pada arah keluar Tol.

2) Rambu peringatan "kurangi kecepatan" dan rumble strip baik pada lajur umum maupun arah keluar Tol.

3) Rambu beri prioritas dari kiri pada arah keluar Tol.

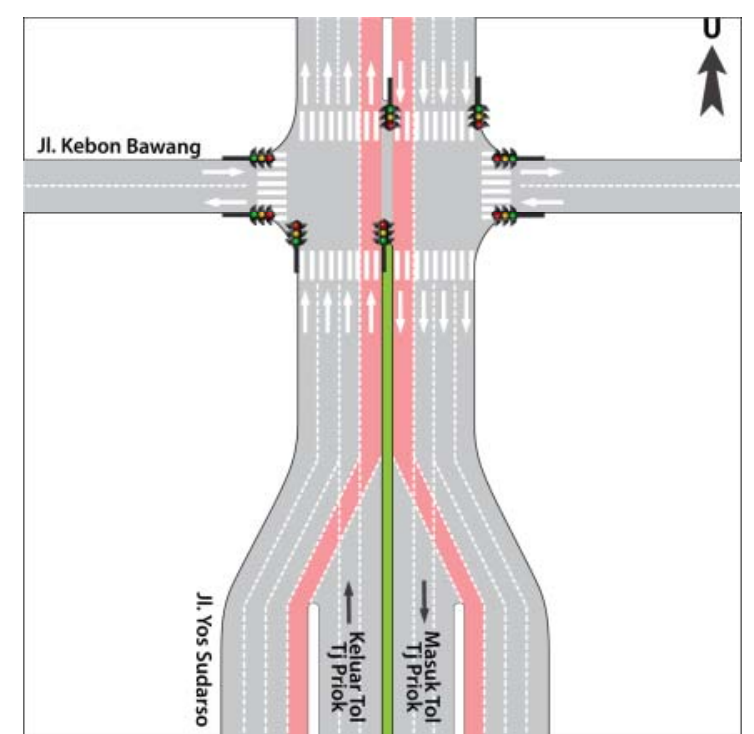

Gambar 4 Sketsa jalur busway dekat pintu tol Tj. Priok. 


\subsection{Lokasi Halte}

Halte yang berada di lokasi yang kurang tepat dapat menimbulkan konflik. Misalnya, halte di Jembatan Dua yang lokasinya berada di kemiringan tanjakan sehingga dapat menyulitkan busway saat berhenti. Apabila tidak memungkinkan untuk dilakukan relokasi terhadap halte busway yang ada, untuk kondisi halte yang memiliki potensi kecelakan perlu dilengkapi dengan sistem perambuan, sehingga tersedia ruang yang aman pada saat menaikkan atau menurunkan penumpang di lokasi halte Busway.

\subsection{Usulan Memperpendek Rute Koridor 10 menjadi Cililitan - Sunter}

Berdasarkan hasil survei TTD (Traffic Time and Delay), untuk seksi halte Plumpang Pertamina sampai dengan halte Sunter ternyata terdapat tundaan yang besar (10 menit). Hal ini terjadi karena adanya manuver truk-truk tangki dan peti kemas melakukan putaran. Kondisi ini rutin terjadi setiap hari sehingga menghambat pergerakan lalulintas umum dan tentunya termasuk TransJakarta bilamana dioperasikan. Oleh karena itu, untuk menghindari tundaan 10 menit atau lebih tersebut pada waktuwaktu sibuk dan waktu-waktu tertentu diusulkan perpendekan rute Cililitan - Enggano menjadi Cililitan - Artha Gading. Usulan ini menjadi lebih mantap dengan kejadian amblasnya jalan R.E. Martadinata yang memperparah tundaan pada seksi Plumpang Pertamina sampai dengan Putaran.

\section{PENANGANAN LOKASI RAWAN KECELAKAAN}

Terdapat beberapa rekomendasi awal yang dapat dijadikan sebagai analisa awal yang ditemukan di lapangan, antara lain titik-titik potensi rawan kecelakaan, dengan diberi penjalasan perkiraan penyebabnya, seperti yang terlihat pada Tabel 1. Pada akhir koridor 10, di kawasan Mega Mall Pluit perlu penanganan yang khusus karena adanya radius kecil, instalasi pompa air dan jalan yang searah (ITDP, 2010). 
Tabel 1 Penanganan Potensi Rawan Kecelakaan di Koridor 10.

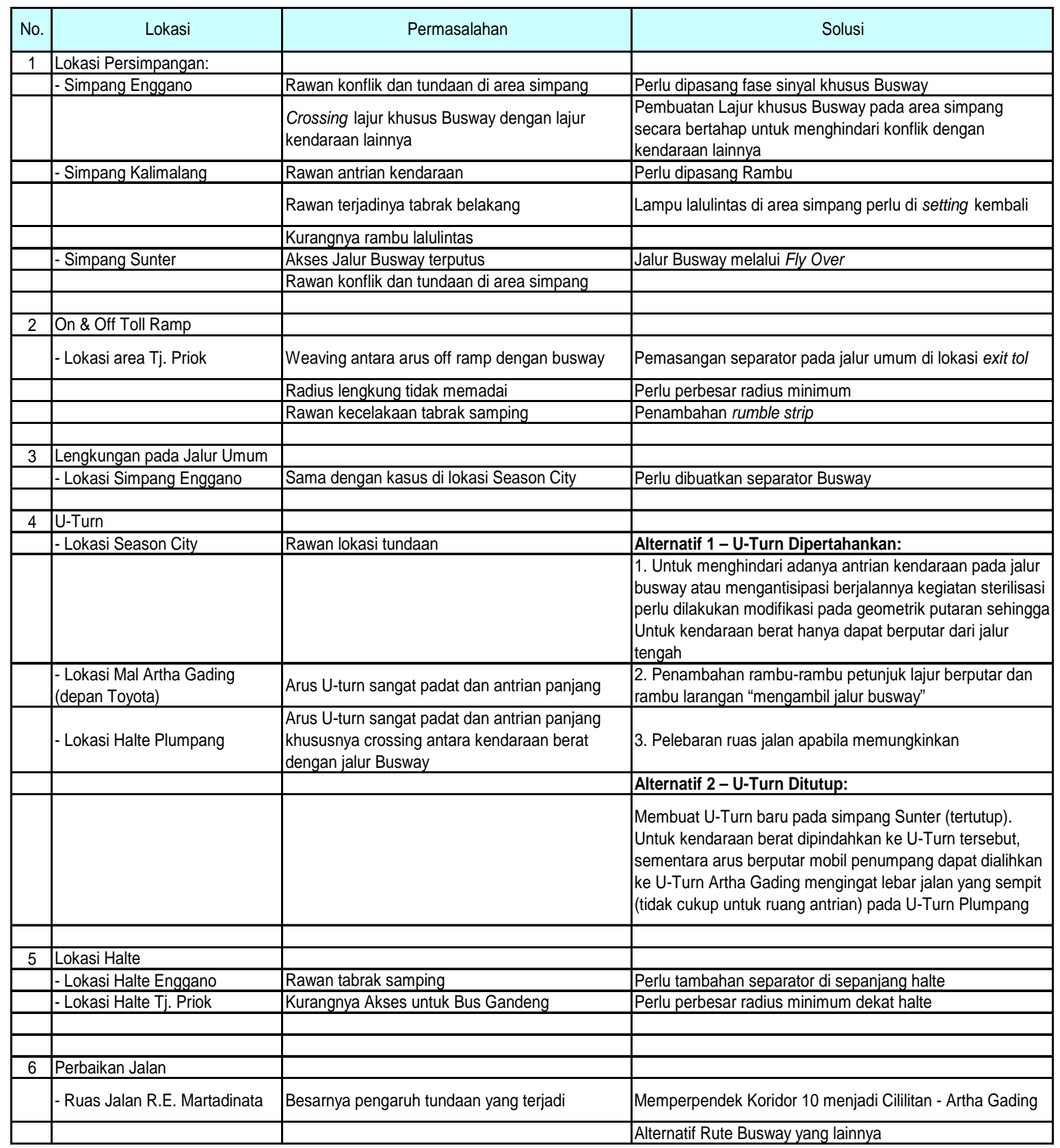


Keterangan:

Lokasi Rawan Kecelakaan (LRK)

Rekomendasi Lokasi Perbaikan (R)

Putaran (U Turn)

Tm Akses Masuk Tol

Tk Akses Keluar Tol

. Halte Transjakarta

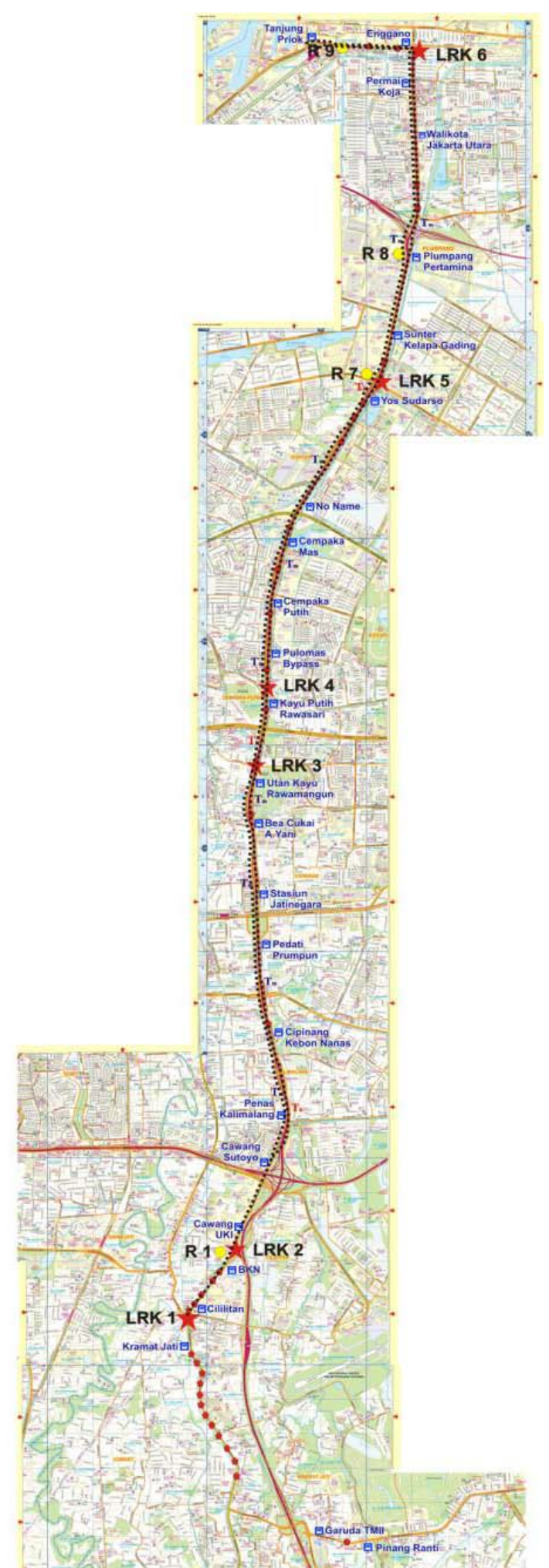

Gambar 5 Investigasi dan Rekomendasi Pencegahan Kecelakaan Lalulintas di Koridor 10.

Studi Potensi Lokasi Rawan Kecelakaan Busway Transjakarta di Koridor 10

(Budi Hartanto Susilo, Firman) 


\section{KESIMPULAN DAN SARAN}

Secara umum kecelakaan transportasi disebabkan oleh salah satu atau kombinasinya dari 3 elemen sistem transportasi yaitu: pengguna jalan, kendaraan dan jalannya itu sendiri termasuk lingkungannya. Dengan memperbaiki elemen-elemen ini diharapkan dapat meningkatkan keselamatan transportasi atau mengurangi potensi kecelakaan lalulintas. Untuk keselamatan lalulintas jalan di Koridor Busway 10 lebih ditekankan kepada desain jalan dan manajemen lalulintas di sepanjang koridor tersebut. Ditinjau dari segi aspek perancangan ada beberapa hal yang harus diperhatikan, yaitu mengenai implementasi desain jalan yang substandar sudah seringkali merenggut korban jiwa.

Hasil inspeksi keselamatan jalan ditemukan ada beberapa kendala yang dapat menyebabkan kecelakaan lalulintas di sepanjang koridor busway 10. Beberapa hal yang perlu diperhatikan mengenai kecelakaan lalulintas jalan di koridor 10 adalah akses pintu tol Tanjung Priok. Banyaknya kendaraan berat yang melewati lokasi tersebut dapat mengakibatkan rawan konflik pada jalur Busway.

Ada beberapa rekomendasi yang diusulkan berdasarkan hasil investigasi Lokasi Rawan Kecelakaan dan pencegahannya yang dilakukan pada lokasi-lokasi yang dianggap paling menghawatirkan dari segi keamanan dan kenyamanan bagi lajur Busway antara lain:

1) Perlu dipasang fase sinyal khusus Busway di lokasi simpang Enggano.

2) Pembuatan lajur khusus Busway pada area simpang secara bertahap untuk menghindari konflik dengan kendaraan lainnya di simpang Enggano.

3) Lampu lalulintas di area simpang Kalimalang perlu di setting kembali untuk menghindari terjadinya kecelakaan tabrak belakang yang diakibatkan oleh banyaknya antrian kendaraan di lokasi simpang.

4) Pemasangan separator pada jalur umum di lokasi exit tol di daerah Tanjung Priok.

\section{DAFTAR PUSTAKA}

1. Dinas Perhubungan DKI Jakarta, (2004). Busway DKI: Lembaran Baru Angkutan Umum Indonesia. Kementerian Perhubungan Republik Indonesia, Jakarta.

2. Fjellstrom, K., (2002), Urban Road Safety. GTZ - Sustainable Transport: A Sourcebook for Policy - Makers in Developing Cities, module 5b, Eschborn.

3. Institute for Transportation and Development Policy, (2010). Evaluation Study of Safety and Traffic Delay in Corridor 9 and 10 prior to Operate. Laporan Akhir, PT. Perentjana Djaja, Jakarta. 
4. Institute of Transportation Engineers (ITE), (1982). Transportation and Traffic Engineering Handbook, $2^{\text {nd }}$ ed., Prentice Hall International Inc., Englewood Cliffs, NJ.

5. Institute of Transportation Engineers (ITE), (1992). Traffic Engineering Handbook, Edisi ketiga, Prentice-Hall, Englewood Cliffs, NJ.

6. Kadiyali, L.R., (1983). Traffic Engineering and Transportation Planning, Khanna Publication, New Delhi.

7. Pemerintah Provinsi DKI Jakarta, (2003). Sustain Human Mobility Bogota. Seminar, Non Government Organization, Jakarta.

8. Odgen, K.W., and Bennet, D.W., (1984). Traffic Engineering Practice, $3^{\text {rd }}$ ed., DOCE, Monash University, Victoria.

9. O’Flaherty, C. A, (1997), Transport Planning and Traffic Engineering, John Wiley \& Sons, Inc., NY.

10. Wright, L., (2002), Bus Rapid Transit. GTZ - Sustainable Transport: A Sourcebook for Policy - Makers in Developing Cities, module 3b, Eschborn.

11. Yu, J.C, (1982). Transportation Engineering-Introduction To Planning, Design, And Operations, Elsevier North Holland, Inc., Amsterdam. 